\title{
CONTEÚDO, LIMITES E INTENSIDADE DOS CONTROLES DE RAZOABILIDADE, DE PROPORCIONALIDADE E DE EXCESSIVIDADE DAS LEIS
}

\author{
HUMBERTO ÁVILA*
}

Introdução. 1. Controle material de constitucionalidade. 1.1 Exame da razoabilidade. 1.2. Exame da proporcionalidade. 1.3. Exame da excessividade. 2. Limites do controle material de constitucionalidade. 2.1 Existência de controle. 2.2 Intensidade do controle. Conclusão.

\section{Introdução}

As intervenções estatais normalmente são qualificadas de excessivas, desproporcionais e irrazoáveis, sendo que essas expressões ora são usadas como tendo o mesmo significado, ora como tendo significados diferentes. Este estudo tem a dupla finalidade de demonstrar, de um lado, que os exames da excessividade, da proporcionalidade e da razoabilidade consistem em diferentes espécies de controle material de constitucionalidade e, de outro, que esses exames, por atingirem aspectos diferentes da aplicação de uma mesma norma, podem ser feitos simultaneamente e conduzir a resultados díspares.

Esses objetivos são atingidos por meio da análise dos diversos modos de controle material de constitucionalidade $\left(1^{\circ}\right.$ parte) e por meio dos limites ao exercício desse controle ( $2^{\mathrm{a}}$ parte).

* Doutor em Direito e Certificado de Estudos em Metodologia da Ciência do Direito pela Universidade de Munique. Mestre em Direito e Especialista em Finanças pela UFRGS. Professor de Direito Tributário, Financeiro e Econômico da Faculdade de Direito da UFRGS. Professor Adjunto Doutor dos Cursos de Mestrado e Doutorado da UFRGS e da UERJ. Advogado e parecerista em Porto Alegre. 


\section{Controle material de constitucionalidade}

\subsection{Exame da razoabilidade}

O postulado da razoabilidade tem sido aplicado pelo Supremo Tribunal Federal como decorrência do princípio do Estado de Direito (art. $1^{\circ}, \mathrm{CF} / 88$ ), que proíbe o exercício arbitrário do poder. ${ }^{1}$ Seguindo o mesmo caminho, a Lei $\mathrm{n}^{\circ} 9.784 / 99$ estabeleceu a razoabilidade como parâmetro da atuação administrativa (art. $2^{\circ}$ ).

A jurisprudência do Supremo Tribunal Federal atribui ao chamado princípio da razoabilidade a fonte para várias exigências.

Em primeiro lugar, a razoabilidade exige a harmonização da norma geral com os casos individucis. Nessa hipótese, a exigência de razoabilidade determina tanto que a interpretação das normas seja feita com a presunção daquilo que normalmente acontece, como aconteceu no caso em que o Supremo Tribunal Federal considerou irrazoável presumir a falta de procuração quando um procurador do Estado apresenta defesa escrita em papel timbrado da procuradoria ${ }^{2}$, quanto que a interpretação das normas gerais seja feita com a consideração de aspectos individuais, como ocorreu no caso em que o Supremo Tribunal Federal qualificou de irrazoável aplicar a norma geral que pune o administrador que contrata servidor sem concurso, no caso de contratação para uma atividade de menor hierarquia, como a de gari. ${ }^{3}$

Em segundo lugar, a razoabilidade impõe a harmonização das normas com as suas condições externas de aplicação. Nessa hipótese, a razoabilidade exige uma causa real justificante para a adoção de qualquer medida. ${ }^{4} \mathrm{O}$ Supremo Tribunal Federal considerou irrazoáveis várias leis: aquela que instituiu um adicional de férias de um terço para os inativos, por tratar-se de vantagem destituída de causa, já que só deve ter adicional de férias quem tem férias ${ }^{5}$, aquela que determinou que os estabelecimentos de ensino expedissem certificados de conclusão do curso e histórico escolar aos alunos que haviam passado no vestibular, mesmo que eles não tivessem sequer frequientado o curso ${ }^{6}$, aquela que determinou que o pagamento dos servidores do Estado fosse feito até o décimo dia útil, por remunerar serviços que ainda não tinham sido sequer prestados. ${ }^{7}$ Além disso, a razoabilidade exige uma relação de congruência entre o fundamento para a diferenciação entre sujeitos e a norma que estabelece a diferenciação. O Supremo Tribunal Federal considerou irrazoáveis as

1 Cf. ÁVILA. Humberto. Teoria dos Princípios: da definição à aplicação dos princípios jurídicos.

2. ed. São Paulo: Malheiros, 2003. p. 94 e ss.

2 Recurso Extraordinário $n^{\circ}$ 192553-1, Segunda Turma, Relator Ministro Marco Aurélio, DJ 16.04.99.

3 Habeas Corpus $n^{\circ}$ 77.003-4, Segunda Turma, Relator Ministro Marco Aurélio, DJ 11.09.98.

4 GAlligAN, Denis James. Discretionary powers. Oxford: Clarendon, 1986. p. 321.

5 Ação Direta de Inconstitucionalidade, Medida Liminar, Tribunal Pleno, Relator Ministro Celso de Mello, DJ 26.05.95.

6 Ação Direta de Inconstitucionalidade n².667-DF, Tribunal Pleno, Medida Cautelar, Relator Ministro Celso de Mello, 19.6.2002.

7 Açāo Direta de Inconstitucionalidade n 247-RJ, Relator Ministro Ilmar Galvão, 17.6.2002. 
seguintes leis: a lei que aumentou o prazo para interposição de ação rescisória somente para o Poder Público, por não existir nenhuma diferença real que autorizasse a distinção ${ }^{8}$ e a lei que contava em dobro o prazo de aposentadoria somente para os secretários de Estado, por não existir qualquer particularidade que justificasse a diferenciação. ${ }^{9}$.

Em terceiro lugar, a razoabilidade exige uma relação de equivalência entre a medida adotada e o critério que a dimensiona. O Supremo Tribunal Federal considerou irrazoável a criação de taxa judiciária, de percentual fixo, por não ser equivalente ao custo real do serviço. ${ }^{10}$ Nesse caso, a multa, além de não ser equivalente ao serviço prestado, ainda impedia o exercício do direito fundamental de acesso ao Poder Judiciário, sendo qualificada de excessiva, como será adiante analisado.

Em quarto lugar, e segundo a jurisprudência do Tribunal de Justiça do Estado do Rio Grande do Sul, a razoabilidade exige uma relação de coerência lógica"' quer no sentido de consistência interna entre as normas jurídicas (p. ex. não é razoável uma lei municipal que estabelece uma obrigação para um sujeito e direciona a punição para outro), quer no sentido de consistência externa da norma com circunstâncias necessárias a sua aplicação (p. ex. não razoável uma lei que impõe uma obrigação que não poderá ser tecnicamente cumprida, desde a edição, porque o órgão incumbido de cumpri-la não é capacitado nem competente para tanto). ${ }^{12}$

Dentre todos esses significados, importa para o caso em pauta um deles: a exigência de relação de equivalência entre a medida adotada e o critério que a dimensiona. Qualquer ato proveniente do Poder Executivo ou do Poder Legislativo que não leve em consideração a relação entre a medida adotada e o critério que a dimensiona, viola o postulado da razoabilidade por desrespeitar os princípios do Estado de Direito e do devido processo legal. Num Estado Democrático de Direito não é tolerável o exercício do poder de forma excludente, desarrazoada, incoerente ou arbitrária. Como lembram GARCIA DE ENTERRÍA e FERNÁNDEZ:

As razões que a autoridade que decide tem de aduzir para excluir a pecha de arbitrariedade têm que ter alguma consistência (...), devem proporcionar um fundamento objetivo capaz de sustentar a decisão, hão de ser, pois, razōes justificativas, suscetiveis de assegurar para a decisão aquilo a que se refere o qualificativo de racional. ${ }^{13}$

8 Açāo Direta de Inconstitucionalidade $n^{\circ}$ 1.753-2, Tribunal Pleno, Relator Ministro Sepúlveda Pertence, DJ 12.06.98.

9 Ação Direta de Inconstitucionalidade, Medida Liminar. Tribunal Pleno, Relator Ministro Sepúlveda Pertence, DJ 22.11.91.

10 Representação $n^{\circ}$ 1077, Revista Trimestral de Jurisprudência do Supremo Tribunal Federal 112/34-67.

"I SCACCIA, Gino. Gli 'strumenti' della ragionevolezza nel giudizio costituzionale. Milano: Giuffrè, 2000. p. 202.

12 Ação Direta de Inconstitucionalidade n 70002017721, Tribunal Pleno do Tribunal de Justiça do Estado do Rio Grande do Sul. Julgamento em 16.09.2002.

13 GARCÍA DE ENTERRfA, Eduardo. FERNÁNDEZ, Tomás-Ramón. Curso de Derecho Admninistrativo. 10. ed. Madrid: Civitas, 2000. p. 478. 
É preciso atentar para o fato de que, no exame de razoabilidade, não há um conflito entre princípios constitucionais surgido em razão de uma medida adotada para atingir um fïm, em razão do qual seja preciso investigar se a utilização do meio produz efeitos que contribuem para a promoção do fim (exame de adequação), se o fim não poderia ser promovido com a adoção de um outro meio que provocasse uma restrição menor a outro princípio constitucional (exame de necessidade) e se as vantagens produzidas com a adoção do meio superam as desvantagens advindas da sua utilização (exame de proporcionalidade em sentido estrito), como ocorre no controle de proporcionalidade. Também não há o exame da invasão do núcleo essencial de um princípio fundamental, como acontece no controle de excessividade.

No exame de razoabilidade-equivalência, o aplicador precisa tão-só investigar - utilizando o exemplo da imposição de uma multa - se o montante da multa guarda relação de equivalência com a gravidade do comportamento que se quer punir, não se avaliando nem a proporcionalidade nem a excessividade. Uma multa pode, em princípio, ser razóivel, porque seu montante mantém relação de equivalência com a gravidade da falta cometida (por exemplo: uma multa elevada aplicada para uma falta grave), mas, ao mesmo tempo, ser excessiva, porque restringe o núcleo de um direito fundamental. e desproporcional, porque a finalidade almejada poderia ser atingida de forma mais suave aos princípios fundamentais.

\subsection{Exame da proporcionalidade}

O postulado da proporcionalidade tem sido aplicado pelo Supremo Tribunal Federal como decorrência dos princípios do Estado de Direito e do devido processo legal (ait. $1^{\circ} \mathrm{e}$ art. $5^{\circ}, \mathrm{LIV}, \mathrm{CF} / 88$ ). Seguindo o mesmo caminho, a Lei $n^{\circ} 9.784 / 99$, além de estibelecer a proporcionalidade como diretriz da administração, exige a sua atuação segundo o critério de adequação entre meios e fins, vedando a imposição de obrigações, restrições e sanções em medida superior àquelas estritamente necessárias ao atendimento do interesse público (art. $1^{\circ}$, parágrafo único, VI). ${ }^{14}$

A jurisprudência do Supremo Tribunal Federal tem aplicado de forma reiterada o chamado princípio da proporcionalidade. O Supremo Tribunal Federal apontou para a máxima garantia dos interesses atingidos quando decidiu que uma obra não pode ser suspensa por ato próprio da autoridade administrativa quando há outros meios específicos à disposição, mesmo que as condições legais sejam contrariadas:

Suspensão de obra pela autoridade administrativa. Esta não pode, por ato próprio, suspender a obra, sem recorrer a via judicial por meio da ação cominatória, que é o remédio específico concedido pela lei, no caso. Código de Processo Civil, artigos 302, XI, e 305. Leva-se ainda em conta que a construção fora licenciada pela autoridade competente, estava em fase adiantada (tivera início onze meses antes) e que, com base e confiança na licença

14 Cf. Á VILA. Humberto. Teoria dos Principios: da definiçăo à aplicação dos princípios jurídicos.

2. ed. São Pilulo: Malheiros, 2003. p. 104 e ss. 
da autoridade. havian surgido interesses de terceiros de boa fé (muitos dos adquirentes de unidades no edifício). Os parágrafos do citado artigo 305 , embora referentes à hipótese de demolição. claramente traduzem o espírito da lei, no sentido de conciliar o interesse público com os demais interesses em causa, ordenando que a construção não seja demolida, mesmo quando contrária às condições legais, se por outro meio se puder evitar o dano ao bem comum. ${ }^{15}$

O Supremo Tribunal Federal também declarou inconstitucional uma lei que determinava que as empresas transportadoras de botijões de gás deveriam possuir, em cada veículo transportador, uma balança especial aprovada pelo órgão competente. Nesse caso, o meio. além de ter sua adequação colociada em dúvida (a balança não seria adequada para pesagem em unidade de massal), foi considerado desnecessário (a fiscalizaçióo por amostragem seria menos restritiva) e desproporcional em sentido estrito (as desvantagens decorrentes de sua utilização - aumento do preço do botijão, deslocimento do consumidor até o caminhão, exigência de investimentos pelas empresas - foram consideradas superiores e, portanto, sem proporção à vantagem - incremento da proteção dos consumidores). ${ }^{16}$

O Supremo Tribunal Federal decidiu que o exame de DNA. requerido por um terceiro, não pode ser exigido do pai presumido, quando há outros meios disponíveis para a comprovação da paternidade. como é o caso da produção do exame pelo próprio terceiro pretendente. Nesse caso, a determinação do exame foi considerada desnecessíria. ${ }^{17}$

Esses precedentes demonstram quie qualquer ato estatal, para ser considerado válido, deve preencher três requisitos: adequação (o meio deve contribuir para a promoção do fim, pois se sua utilização só é justificada pelo tim. não sendo ele promovido, o uso do meio acaba não mais possuindo justificativa), necessidade (o meio deve ser o mais suave dentre os meios disponíveis, pois o Estado não apenas tem a obrigação de atingir seus fins próprios, mals, também, tem a obrigação de proteger ao máximo os direitos dos particulares, e isso somente é possível se ele adotar o meio menos restritivo) e proporcionalidade em sentido estrito (o meio deve proporcionar vantagens superiores as desvantagens, pois o Estado, tendo obrigação de realizar todos os princípios constitucionais. não pode adotar um meio que termine por restringi-los mais do que promovê-los em seu conjunto).

Além disso, qualquer atuação estatal deve ser precedida de uma ponderação de todos os interesses em jogo. Trata-se de uma exigência de racionalidade: se a medida destina-se a todos e a todos alcança, deve ser adotada mediante a consideração do

I5 Recurso de mandado de segurança n 13.140. Relator: Ministro Luiz Gallotti, DJ 16.12.64, S. 04649.

16 Ação Declaratória de Inconstitucionalidade n 855-2. Relator: Ministro Ministro Sepúlveda Pertence, DJU 01.10.93.

17 Habeas Corpuss n 76060-SC. Relator: Ministro Sepúlveda Pertence. DJ 15.05.98, S. 44. 
interesse de todos. ${ }^{18}$ Não só dos interesses do Poder Público, mas dos interesses de todos os grupos sociais atingidos pela medida. $O$ dever do poder público de conciliar os interesses em jogo foi, inclusive, reconhecido pelo Supremo Tribunal Federal:

Atualmente o poder de tributar () é o poder de conservar, de manter, conciliando assim as necessidades do Estado com os direitos assegurados ao individuo. ${ }^{19}$

A exigência de conciliar os interesses em jogo é, por vezes, denominada de concordância prática entre os interesses. Essa exigência também é encampada pelo Supremo Tribunal Federal:

Representação de inconstitucionalidade de lei. Artigos 15, parágrafo $3^{\circ}$ e 17 da Lei $n^{\circ} 5.991$, de 17.12.73. Limitação à liberdade de comércio. Drogarias. A norma que prevê a assistência do técnico responsável nas drogarias visa a concordancia prática entre a liberdade do exercicio do comércio de medicamentos e o seu controle, em benefício dos que visam tais medicamentos. ${ }^{20}$

Registre-se, por fim, que quanto maior for a restrição causada a um direito fundamental, maior deverá ser a sua razão justificativa. Uma restrição em grau elevado exige uma justificação na mesma medida. ${ }^{21}$

\subsection{Exame de excessividade}

O postulado da proibição de excesso tem sido aplicado pelo Supremo Tribunal Federal, normalmente em associação com a proporcionalidade (art. $1^{\circ} \mathrm{e}$ art. $5^{\circ}, \mathrm{LIV}$, $\mathrm{CF} / 88$ ) ou com a liberdade de comércio (art. 170, parágrafo único, $\mathrm{CF} / 88$ ). Ele fundamenta-se na idéia de que todos os direitos e princípios fundamentais, ainda que possam ser restringíveis, não podem ser atingidos no seu núcleo essencial, sendo esse núcleo definido como aquela parte do conteúdo de um direito sem a qual ele perde a sua mínima eficácia e, por isso, deixa de ser reconhecível como um direito fundamental. ${ }^{22}$

A Segunda Turma do Supremo Tribunal Federal decidiu por negar provimento a um Recurso Extraordinário por entender excessiva e desproporcional a majoração do imposto de licença sobre as cabines de banho. A recorrente aduziu que tal

18 HABERMAS, Jürgen. Faktizität und Geltung: Beiträge zur Diskurstheory des Rechts und des demokratischen Rechtsstaates. Darmstradt: Wissenschftliche Buchgesellschaft, 1994. pp. 267 e 317. ALEXY, Robert. Recht, Vernunft, Diskurs. Frankfurt am Main: Suhrkamp, 1995. p. 171.

19 Recurso Extraordinário N 18.976, Relator: Ministro Barros Barreto, ADJ 26.11.52, S. 14653, p. 15 do acórdão, que se refere à decisão recorrida.

20 Representaçĩo n 1507, Tribunal Pleno, Relator Ministro Carlos Madeira, DJ 09.12.88.

21 CLERICO. Laura. Die Strukuur der Verhältnismäßigkeit. Baden-Baden: Nomos, 2001. p. 189.

22 Cf. ÁVILA, Humberto. Teoria dos Princípios: da definição à aplicação dos princípios jurídicos.

2. ed. São Paulo: Malheiros, 2003. p. 89 e ss. 
imposição poderia the cercear uma atividade lícita e, por isso, estaria colidindo com o princípio da liberdade de qualquer profissão (art. 141, § 14 da Constituição de 1946). O voto do Ministro Orozimbo Nonato faz referência à decisão da Suprema Corte Americana no sentido de que:

"o poder de taxar somente pode ser exercido dentro dos limites que o tornem compativel com a liberdade de trabalho, de comércio e de indústria e com o direito de propriedade". ${ }^{23}$

O Supremo Tribunal Federal, analisando a constitucionalidade da majoração do antigo imposto de licença, asseverou:

A meu ver, porém, faz-se dispensável qualquer referência expressa nesse sentido, pois os próprios dispositivos fundamentais, que asseguram as liberdades individuais, entre os quais se incluiu o exercício de qualquer profissão, comércio e indústria. constituem uma implícita limitação ao poder de tributar do Estado, no concernente à criação de impostos exagerados, vedando, por conseqüência, que a administraçāo, por meio de tributos excessivos, possa tolher, cercear ou dificultar o pleno exercício dos direitos básicos conferidos ao cidadão". ${ }^{24}$

O importante é que foi reconhecido um limite implícito ao poder de tributar, não apenas no sentido de acabar plenamente com a atividade da empresa, mas, também, no sentido de "tolher, cercear ou dificultar o pleno exercício dos direitos básicos conferidos ao cidadão".

Noutro caso, a Primeira Turma do Supremo Tribunal Federal reconheceu o direito à cobrança do imposto do selo, mas modificou o entendimento em relação ao valor da multa, considerando-a excessiva relativamente ao direito de propriedade e de liberdade. ${ }^{25}$

O Supremo Tribunal Federal tem igualmente considerado inconstitucionais as restrições administrativas que, ainda que não bloqueiem de modo absoluto, certamente embaraçam o seu livre exercício:

Penso, porém, que, ao estatuir essa exigência, fato que tenho como certo, visto não haver sido contestado, a autoridade arrecadadora estabeleceu, em verdade, sanção fiscal, que, se não impediu totalmente, bloqueou de modo profundo a atividade profissional lícita do contribuinte, violando, de tal

23 Recurso Extraordinário n. ${ }^{\circ}$ 18.331/SP, Relator Ministro Orozimbo Nonato, DJ 21.09.1951.

24 Recurso Extraordinário n 18.976, Relator: Ministro Barros Barreto, ADJ 26.11.52, S. 14653, p. 15 do acórdāo, que se refere à decisão recorrida.

25 Recurso Extraordinário $n^{\circ}$ 47.937/Guanabara, Relator: Ministro Cândido Motta, DJ 06.12.62. 
arte, o aludido preceito constitucional, sem falar na violação da Súmula 547.26

Noutro julgamento, o Plenário do Supremo Tribunal Federal decidiu por deferir medida liminar que suscitava a inconstitucionalidade de Lei Estadual que elevava os valores de taxa judiciária. O fato de a taxa judiciária ter sido elevada em $827 \%$ restringiria excessiramente o direito de acesso ao Poder Judiciário a uma grande parcela da população. ${ }^{27}$

O Supremo Tribunal Federal também decidiu pela inconstitucionalidade da restrição tributária em virtude do seu conteúdo arbitrário, da seguinte forma:

Ademais, é de considerar-se que esta Turma, ao julgar o RE 76.455 (RTJ 73/82 l e segs.). em caso análogo ao presente (tratava-se de exigência, a contribuinte submetido ao regime especial de controle de fiscalização, de pagamento antecipado do ICM, para entrega de talonários referentes a esse imposto), decidiu que restrição dessa ordem importava sanção política, vedada pelo $\$ 23$ do artigo 153 da Constituição, sendo aplicável a Súmula 547.

$\mathrm{Na}$ hipótese, a matéria, como lembrado, foi regulada pelo Decreto $\mathrm{n}^{\circ}$ 17.727/81, deixando, além disso, inaceitaivel margem de arbítrio para a aplicaşäo pela autoridade fiscal, ${ }^{28}$

O Supremo Tribunal Federal. seguindo o precedente anterior, considerou inconstitucional a restrição arbitrália e excessiva ao princípio do livre exercício de atividade econômica, da seguinte forma:

A questão de saber da constitucionalidade das medidas aplicadas no " regime especial" de pagamento do ICM é matéria já conhecida desta Corte, que, pelo menos em três assentadas, pelas suas duas Turmas, teve ocasião de pronunciar-se em sentido contrário à sua imposição, sob o fundamento de que as sanções, cominadas ao contribuinte, carecem de respaldo constitucional, particularmente à vista da inaceitável margem de arbítrio aos agentes do Fisco.

O certo é que o "regime especial do ICM", mesmo autorizado por lei, porque impõe restrições e limitações à atividade comercial do contribuinte,

26 Recurso Extraordinário $n^{\circ}$ 76.455, Relator Ministro Leitão de Abreu, Decisão em 01.04.75, Revista Trimestral de Jurisprudência $n^{\circ} 73: 825$.

27 Representação n 1.077-5/RJ. Relator Ministro Moreira Alves, DJ 26.02.1981.

28 Recurso Extraordinairio $n^{\circ}$ 106.759, Relator Ministro Oscar Corrêa, Decisão em 24.09.85, Revista Trimestral de Jurisprudencia n“ 115:1443. 
viola a garantia da liberdade de trabalho, que estava inscrita no art. 153. $\S 23$, da Constituição de 1988 reafirma no art. $5^{\circ}$, XIII. ${ }^{24}$

Noutro caso já mencionado. o Supremo Tribunal Federal analisou a obrigatoriedade de utilização de balanças especiais por veículos transportadores de botijões de gás. Dentre as várias alegações, uma delas diz respeito à proibição de excesso: os efeitos da utilização do meio poderiam provocar à restrição excessiva do direito fundamental de livre iniciativa (a utilização de balanças poderia levar as empresas “à ruína"). ${ }^{30}$

O Supremo Tribunal Federal, em caso também já referido, entendeu que submeter o pai presumido ao constrangimento de fazer um exame de DNA para provar a paternidade de um terceiro restringiria excessivamente a dignidade humana. ${ }^{31}$

O Supremo Tribunal Federal também veda o exercício arbritrário do poder, entendido esse como aquele que é praticado de modo imoderado e que, por isso, afeta substancialmente o patrimônio e os rendimentos do contribuinte, como demonstra a decisão que aponta a excessividade com o nome de violação à razoabilidade:

Resulta configurado o caráter confiscatório de determinado tributo, sempre que o efeito cumulativo - resultante das múltiplas incidências tributárias estabelecidas pela mesma entidade estatal - afetar, substancialmente, de maneira irrazóvel, o patrimônio elou os rendimentos do contribuinte. O Poder Público, especialmente em sede de tributação (as contribuições de seguridade social revestem-se de caráter tributário), não pode agir imoderadamente, pois a atividade estatal acha-se essencialmente condicionada pelo princípio da razoabilidade. (...) ${ }^{32}$

Em todos esses casos, o Supremo Tribunal Federal constatou que nenhuma medida estatal pode: (a) restringir excessivamente um direito fundamental, inviabilizando-o substancialmente, independentemente do seu motivo; (b) cercear. tolher ou dificultar sobremaneira o livre exercício da atividade econômica. ainda que a medida não inviabilize por completo a atividade empresalrial.

O controle de excessividade independe da sua justificação (verificável noutros exames), pois importa verificar a restrição do núcleo essencial de um direito fundamental. Nessa perspectiva, não há propriamente exame entre princípios colidentes para ver se o fim justifica a utilização do meio (exame da proporcionalidade), nem

29 Embargos no Recurso Extraordinário n 115.452. Relator: Ministro Carlos Velloso, Decisão em 04.10.90. Revista Trimestral de Jurisprudência n 138:849-50.

30 Ação Declaratória de Inconstitucionalidade $n^{\circ}$ 855-2, Relator: Ministro Ministro Sepúlveda Pertence, DJU 01.10.93.

31 Habeas Corpus n 76060-SC. Relator: Ministro Sepúlveda Pertence. DJ 15.05.98. p. 44.

32 Medida Cautelar na Ação Direta de Inconstitucionalidade n ${ }^{\circ} 2010$. Relator Ministro Celso de Mello, DJ 12.04.02 
um controle de proporção entre a gravidade da penalidade e a falta cometida (exame da razoabilidade-equivalência). O que há é uma exigência de um limite, além do qual o núcleo de um princípio fundamental é atingido e, por isso, ele não tem um mínimo de eficácia. Tanto a proibição de excesso não se identifica com a razoalibilidade-equivalência que o próprio Supremo Tribunal Federal decidiu que a primeira diz respeito a um limite acima do qual há restrição a um direito fundamental e a segunda diz respeito a relação entre a punição e a gravidade da conduta punida. Assim a decisão:

Conheço do recurso e the dou parcial provimento para julgar procedente o executivo fiscal, salvo quanto à multa moratória que, fixada em nada menos do que $100 \%$ do imposto devido, assume feição confiscatória. Reduzo-a para $30 \%$ (trinta por cento), base que reputo razoável para a reparação da impontualidade do contribuinte. ${ }^{33}$

Neste julgamento, fica claro que a excessividade (ou confiscatoriedade) representa a restrição excessiva de um direito fundamental. Uma vez decidido que uma multa é excessa, é preciso verificar, então, qual o montante em que ela deve ser fixada. Para isso, é preciso investigar qual falta a multa pretende punir. Por isso que - Supremo Tribunal Federal decidiu. de um lado, que a multa moratória de $100 \%$ assume feição confiscatória (exame da proibição de excesso) e, de outro, que a sua fixação em $30 \%$ é razoável para a reparação da impontualidade (exame da razoabilidade-equivalência). No exame da proibição de excesso investiga-se a existência de restrição excessiva a um direito fundamental, nada sendo dito com relação a qual percentual seria razoável; no exame da razoabilidade-equivalência analisa-se justamente a relação entre o montante da multa e a falta cometida, nada sendo dito com relação a invasão do núcleo de um direito fundamental.

\section{Limites do controle material de constitucionalidade}

\section{I Existência de controle}

A declaração de inconstitucionalidade de uma intervenção estatal pela violação à razoável, proporcional e não-excessiva aplicação dos princípios constitucionais pode conduzir à exclusão total da norma incompatível com a Constituição ou à substituição do percentual por ela estabelecido. Nessa segunda hipótese, pergunta-se: a atuação do Poder Judiciário não violaria o princípio da separação dos poderes (art. $2^{\circ}$ da $\left.\mathrm{CF} / 88\right)$ ?

Exatamente sobre essa questão o Supremo Tribunal Federal desenvolveu a tese do legislador negativo para indicar que o Poder Judiciário tem a função de legislar

33 Recurso Extraordinário $n^{\circ} 81.550$, Relator: Ministro Xavier de Albuquerque, decisão em 20.05.75, Revista Trimestral de Jurisprudencia $n^{\circ} 74: 319-320$. 
negativamente, no sentido de eliminar do ordenamento jurídico a norma incompatível com a Constituição, mediante um juízo de exclusão, não podendo criar norma jurídica geral diversa da instituída pelo Poder Legislativo. ${ }^{34}$

Logo se percebe que há dois fundamentos concorrentes para a tese do legislador negativo, um de natureza formal e outro de caráter material. O fundamento de natureza formal (procedimental) consistiria na proibição de pronunciamento positivo por parte do Supremo Tribunal Federal, em sede de controle abstrato de constitucionalidade, mediante criação de norma geral, por ser esse controle circunscrito ao exame da compatibilidade da norma com a Constituição, e conducente a um juízo de exclusão/eliminação do ordenamento jurídico da norma incompatível com a Constituição. O fundamento material consistiria na proibição de o Poder Judiciário exercer competência privativa do Poder Legislativo, seja alterando norma que este Poder instituiu, seja criando norma que ele deixou de editar, pois fazê-lo, nesses casos, importaria na violação do princípio da Separação dos Poderes.

A análise desses fundamentos permite verificar que a tese do legislador negativo não pode ser utilizada de modo incondicional. Em primeiro lugar, porque ela não se aplica a qualquer caso. Com efeito, quando houver uma limitação de ordem procedimental (no controle concentrado, como se trata de aferir a constitucionalidade de lei em tese, deve-se analisar a lei tal como posta), aí sim existe um limite à competência do Poder Judiciário. Quando, porém, não houver limite decorrente do objeto da ação, não se pode impedir o Poder Judiciário de instituir a norma individual para o caso concreto. Bem ao contrário: é dever do Poder Judiciário dizer o Direito. Isso revela, pois, que o uso irrestrito dessa tese pelos tribunais inferiores, baseado sobretudo na sua idéia geral desatrelada dos fundamentos que lhe atribuem conteúdo de sentido (simplesmente "o Poder Judiciário não pode pronunciar-se positivamente sobre questões jurídicas já constantes de lei") pode constituir verdadeiro repúdio ao dever constitucional atribuído ao Poder Judiciário de julgar o caso concreto e a total negação do direito fundamental da universalidade da jurisdição.

Em segundo lugar, o uso incondicional da tese do legislador negativo negligencia a inarredável necessidade de construção das significações normativas pelo Poder Judiciário. De fato, o próprio fundamento da teoria do legislador negativo é incorreto, na medida em que parte do pressuposto de que há significados incorporados ao texto e normas com sentido inequívoco. Ora, não há nem significação incorporada ao texto nem significados inequívocos, como já analisado. As significações nunca estão prontas, mas devem ser exatamente construídas mediante atos de decisão do próprio Poder Judiciário. A tese do legislador negativo ainda conduz, de modo imperceptível, a uma equiparação da hipótese em que o Poder Judiciário não pode agir positivamente (proibição de preenchimento de lacunas como planejadas incompletudes decorrente de as leis não conterem normas apesar de o ordenamento jurídico as exigir), com as hipóteses em que ele deve exatamente atuar de modo positivo, quer utilizando métodos como argumentum e contrario (atribuir sentido ao que o legislador, ao

34 Exemplo: Ação Direta de Inconstitucionalidade - Medida Cautelar n 896, Relator Ministro Moreira Alves, DJ 16.02.96, pp. 02.997. 
regular somente um caso. determinou relativamente a outros diferentes), redıção teleológica (reduzir o sentido das palavras da lei por serem elas muito amplas em relação a sua finalidade) e extensão teleológica (ampliar o sentido das palavras da lei por serem elas muito restritas em relação a sua finalidade), quer simplesmente concretizando definitoriamente e mediante regras de prevalência aquilo que o ordenamento jurídico estatui por meio dos princípios fundamentais. ${ }^{35}$ Interpretar não é nem simplesmente enquadrar um fato ou comportamento numa classe de fatos ou comportamentos, nem só atribuir um significado a palavras ou enunciados: interpretar é também fazer suposiçōes sobre finalidades e intenções de agentes ou construir conjecturas sobre as relações de causa e efeito entre fatos. ${ }^{36}$ De qualquer modo, a interpretação consiste numa atividade complexa de relacionar elementos sintáticos, semânticos e pragmáticos segundo estruturas fornecidas por postulados hermenêuticos. ${ }^{37}$ Nesses casos, o Poder Judiciário não é chamado a criar uma norma para um caso não regulado mediante operação de similitude com casos já regulados, mas convocado a construir o próprio significado da norma em função da sua finalidade, que só estava entremostrada antes da delimitação do caso a ser julgado. Ora, restringir a atuação do Poder Judiciário ao aspecto negativo não é só desconhecer as hipóteses em que não é sequer racionalmente concebível desconjuntar a dimensão negativa da positiva ou mesmo prescindir do caráter multifacetado das normas jurídicas; é também olvidar a indispensável faculdade positiva de o Poder Judiciário constituir o Direito diante do caso concreto, e terminar por permitir um incontornável apoucamento do significado normativo dos princípios e regras constitucionais que protegem o contribuinte.

É preciso considerar, no caso do controle de constitucionalidade das multas, que o próprio Supremo Tribunal Federal - que utiliza a tese do legislador negativo — tem substituído o percentual das multas mediante a utilização de parâmetros legais estabelecidos pelo próprio Poder Legislativo para casos análogos. Vale dizer, o Poder Judiciário não está substituindo o Poder Legislativo. mas pensando coerentemente aquilo mesmo que o Poder Legislativo, atuando nos limites estabelecidos pela Constituição, previu para casos análogos.

\subsection{Intensidade do controle}

Outra questão é deliminar a intensidade desse controle, vale dizer, descobrir se o controle feito pelo Poder Judiciário relativamente aos atos provenientes dos Poderes Legislativo e Executivo deve ser forte. médio ou fraco.

35 CANARIS, Claus-Wilhelm. Die Feststellung von Lïcken im Gesetz. 2. ed. Berlin: Duncker und Humblot, 1983. pp. 82 e ss.

36 GUASTINI. Riccardo. Interprétation et description de normes. In: Interpretation et Droit. Org. Paul Anselek. Bruxclles: Bruylant. 1995. 90 e 91.

37 ALEXY, Robent. Juristische Interpreation. In: Recht, Vermunfi. Diskurs. Frankfurt am Main: Suhrkanp, 1995. p. $76 \mathrm{ess}$. 
É certo que o Poder Legislativo, justamente porque toma decisões resultantes de discussões e votações democráticas, tem uma liberdade de configuração (Gestaltungsfreiheit) ou margem de apreciação (Beurteilungsspielraum) relativamente ao conteúdo dos seus atos. Em razão dessa maior capacidade para avaliar as decisões, o Poder Legislativo tem uma espécie de prerrogativa de avaliação (Einschätzungsprärrogative): poder de escolher entre mais de uma premissa concreta duvidosa que irá restringir algum direito fundamental e servirá de ponto de partida para o controle pelo Poder Judiciário. Isso significa que a premissa escolhida pelo Poder Legislativo como justificativa para restringir um direito fundamental não poderá ser simplesmente substituída pelo Poder Judiciário no controle de constitucionalidade. Daí a afirmação de que esse poder inclui a prerrogativa de escolher as premissas empíricas (Festsetzungsprärrogative) a serem utilizadas na tomada de decisão. Por exemplo, é o Poder Legislativo o órgão competente para avaliar qual a melhor medida para combater uma epidemia e se ele entender que é o consumo de carne bovina que está causando a doença, porque existe um nexo de causalidade entre o consumo e o aumento da epidemia, não poderá o Poder Judiciário partir de outra premissa para analisar a constitucionalidade da lei. O Poder Legislativo também possuiria, por conseqüência, uma margem de prognose (Prognosespielraum) relativamente à previsão dos efeitos futuros da adoção de uma medida que visa a promover efeitos relativos ao interesse público. ${ }^{38}$

É também certo, porém, que o exercício dessas prerrogativas decorrentes do princípio democrático deve ser controlado pelo Poder Judiciário, especialmente porque restringe direitos fundamentais. Em vez da insindicabilidade dessas decisões (Nichtjustitiabilität), é preciso verificar em que medida essas competências estão sendo exercidas. Nesse sentido, é importante atentar para os critérios que aumentam e que restringem o controle material exercido pelo Supremo Tribunal Federal, critérios esses que podem ser construídos a partir mesmo de argumentos principiológicos baseados na Constituição Federal de 1988.

De um lado, o controle pelo Poder Judiciário e a exigência de justificação da restrição a um direito fundamental deverão ser tanto mais intensos, quanto maior for:

(1) a condição para que o Poder Judiciário construa um juízo seguro a respeito da matéria tratada pelo Poder Legislativo;

(2) a evidência de equívoco da premissa escolhida pelo Poder Legislativo como justificativa para a restrição do direito fundamental;

38 RAABE, Marius. Grundrechtsschutz und gesetzgeberischer Einschätzungsspielraum - Eins Konstruktiosvorschlag. In: Allgemeinheit der Grundrechte und Vielfalt der Gesellschaft. Org. Christoph Grabenwarter. Stuttgart: Boorberg, 1994. p. 94 ss. RAU, Christian. Selbst entwickelte Grenzen in der Rechtsprechung des United States Supreme Court und des Bundesverfassungsgerichts. Berlin: Duncker und Humblot, 1996. p. 190 ss. 
(3) a restrição ao bem jurídico constitucionalmente protegido;

(4) a importância do bem jurídico constitucionalmente protegido, a ser aferida pelo seu caráter fundante ou função de suporte relativamente a outros bens (por exemplo, vida e igualdade) e pela sua hierarquia sintática no ordenamento constitucional (por exemplo, princípios fundamentais).

Presentes esses fatores, maior deverá ser o controle exercido pelo Poder Judiciário, notadamente quando a premissa utilizada pelo Poder Legislativo for evidentemente errônea. Nesse sentido, incumbe ao Poder Judiciário "avaliar a avaliação" feita pelo Poder Legislativo (ou pelo Poder Executivo) relativamente à premissa escolhida. justamente porque o Poder Legislativo só irá realizar ao máximo o princípio democrático se escolher a premissa concreta que melhor promova a finalidade pública que motivou sua ação ou se tiver uma razão justificadora para ter se afastado da escolha da melhor premissa. Se o Poder Legislativo podia ter avaliado melhor, sem aumento de gastos, a sua competência não for exercida em consonância com o princípio democrático que lhe incumbe realizar.

De outro lado, o controle pelo Poder Judiciário e a exigência de justificação da restrição a um direito fundamental deverão ser tanto menos intensos, quanto mais:

(1) duvidoso for o efeito futuro da lei;

(2) difícil e técnico for o juízo exigido para o tratamento da matéria;

(3) aberta for a prerrogativa de ponderação atribuída ao Poder Legislativo pela Constituição;

Presentes esses fatores, menor deverá ser o controle exercido pelo Poder Judiciário, já que se torna mais difícil uma decisão autônoma desse Poder. Em qualquer caso - e este é o ponto decisivo - caberá ao Poder Judiciário verificar se o legislador fez uma avaliação objetiva e sustentável do material fático e técnico disponível, se esgotou as fontes de conhecimento para prever os efeitos da regra do modo mais seguro possível e se se orientou pelo estágio atual do conhecimento e da experiência. ${ }^{34}$ Se tudo isso foi feito - mas só nesse caso - a decisão tomada pelo Poder Legislativo é justificável sustentável (vertretbar) e impede que o Poder Judiciário substitua a sua avaliação. Mas, veja-se: a decisão a respeito da justificabilidade da medida adotada pelo Poder Legislativo é o resultado final do controle feito pelo Poder Judiciário e, não, uma posição rígida e prévia anterior a ele. Sem o controle do Poder Judiciário não há sequer como comprovar a justificabilidade da medida adotada por outro Poder.

39 RAU, Christian. Selbst entwickelte Grenzen in der Rechtsprechung des United States Supreme Court und des Bundesverfassungsgerichts. Berlin: Duncker und Humblot, 1996. p. 192 ss. 
Todas essas consideraçôes levam ao entendimento de que o controle de constitucionalidade poderá ser mais ou menos intenso, mas sempre existirá, devendo ser afastada, de plano, a solução simplista de que o Poder Judiciário não pode controlar outro poder com base no princípio da separação dos poderes. O princípio democrático só será realizado se o Poder Legislativo escolher premissas concretas que levem à realização dos direitos fundamentais e das finalidades estatais. Os direitos fundamentais, quanto mais forem restringidos e mais importantes forem na ordem constitucional, mais devem ter sua realização controlada. A tese da insindicabilidade das decisões do Poder Legislativo, sustentada de modo simplista, é uma monstruosidade que viola a função de guardião da Constituição atribuída ao Supremo Tribunal Federal, a plena realização do princípio democrático e dos direitos fundamentais bem como a concretização do princípio da universalidade da jurisdição.

\section{Conclusão}

Este estudo visa a demonstrar que os exames da razoabilidade, da proporcionalidade e da excessidade são distintos, já que envolvem a relação de elementos diversos em face de parâmetros diferentes.

Com efeito, o exame de razoabilidade-equivalência investiga a relação entre duas grandezas ou entre uma medida e o critério que informa sua fixação. $O$ exame de proporcionalidade investiga a relação entre a medida adotada, a finalidade a ser atingida $\mathrm{e} o$ grau de restrição causado nos direitos fundamentais atingidos. $\mathrm{O}$ exame da proibição de excesso analisa a existência de invasão no núcleo essencial de um princípio fundamental.

Com essas considerações fica claro que os exames de razoabilidade, proporcionalidade e excessividade consistem em exames concretos diferentes uns dos outros. Com essas observações fica também evidente por que há tanta confusão entre esses exames: as expressões "razoabilidade", "proporcionalidade" e "excessividade", quando não utilizadas em razão do exame concreto que visam a representar, podem fazer referência a exames concretos diferentes. Sendo a irrazoabilidade, no exemplo da multa, a falta de equivalência entre o montante da multa e a gravidade da conduta a ser punida, pode-se expressar essa falta de equivalência tanto dizendo que não há "proporção" entre o montante da multa e falta cometida quanto afirmando que o montante da multa "excede" aquilo que seria adequado para punir a falta praticada. O mesmo vale para os outros casos.

Isso quer dizer, então, que toda a discussão a respeito da "razoabilidade", da "proporcionalidade" e da "excessividade" diz respeito apenas a um problema de consenso? Não. Quer dizer, em vez disso, que essas expressões são ambíguas e que devem ser definidas, sendo secundário decidir qual delas será utilizada para cada exame. O que deve ficar claro - e este é o problema central - é que há três diferentes exames concretos que não podem ser confundidos, pois envolvem elementos distintos relacionados com parâmetros diversos. O problema não está em usar essa ou aquela expressão, mas em confundir exames concretos diferentes pelo uso unificado de uma só expressão ou pelo uso alternativo de várias expressões. Dito 
de outro modo: o problema não está em usar uma palavra para três fenômenos, mas não perceber que há três fenômenos diferentes a analisar.

Importa registrar, por fim, que em todos esses exames, sempre há um raciocínio que é feito relativamente à aplicação de outras normas do ordenamento jurídico. No exame da razoabilidade-equivalência, analisa-se a norma que institui a intervenção ou exação com a finalidade de verificar se há equivalência entre o sua dimensão e a falta que ela visa a punir. No exame de proporcionalidade, investiga-se a norma que institui a intervenção ou exação para verificar se o princípio que justifica sua instituição será promovido e em que medida os outros princípios serão restringidos. É por esse motivo que, nesse exame, vem à tona a restrição maior ou menor aos princípios fundamentais. No exame de proibição de excesso, analisa-se a norma que institui a intervenção ou exação para comprovar se algum princípio fundamental não está sendo atingido no seu núcleo. Por esse motivo que surge a questão de saber se há uma restrição excessiva dos princípios fundamentais.

Isso demonstra que esses exames investigam o modo como devem ser aplicadas outras normas, quer estabelecendo os critérios, quer estabelecendo as medidas. De qualquer forma, as exigências decorrentes da razoabilidade, da proporcionalidade e da proibição de excesso vertem sobre outras normas, não, porém, para atribuir-lhes sentido, mas para estruturar racionalmente sua aplicação. Sempre há uma outra norma por trás da aplicação da razoabilidade, da proporcionalidade e da excessividade. Por esse motivo é oportuno tratá-las como metanormas. E como elas estruturam a aplicação de outras normas, com elas não se confundindo, é oportuno fazer referência a elas com outra nomenclatura. Daí a utilização do termo "postulado", a indicar uma norma que estrutura a aplicação de outras.

Os postulados se diferenciam das normas cuja aplicação estruturam em várias perspectivas: quanto ao nível (os postulados situam-se no metanível ou no segundo nível e as normas objeto de aplicação situam-se no nível objeto ou no primeiro nível), quanto ao objeto (os postulados indicam a estrutura de aplicação de outras normas e as normas descrevem comportamentos, se forem regras, ou instituem a promoção de fins, se forem princípios) e quanto ao destinatário (os postulados se dirigem aos aplicadores e as normas a quem deve obedecê-las).

Essas sutilezas apontadas quanto à natureza da espécie normativa que está sendo utilizada e quanto ao controle que é exercido contribuem decisivamente para a maior efetividade dos princípios constitucionais, pois o aplicador tem melhores condições de saber o que deve ser fundamentado, o que deve ser comprovado e quais as normas cuja restrição ou efetividade está sendo analisada. 